\title{
ANALISIS MAKNA IMPLIKATUR DALAM WACANA IKLAN LAYANAN MASYARAKAT PADA MEDIA SOSIAL
}

\author{
oleh \\ Novita Sari, Radhiah* ${ }^{*}$ \& Safriandi \\ *Dosen Program Studi Pendidikan Bahasa Indonesia, FT Universitas Malikussaleh \\ Surel: radhiah@unimal.ac.id
}

\begin{abstract}
ABSTRAK
Penelitian ini bertujuan untuk mendeskripsikan analisis wacana berupa implikatur dalam iklan layanan masyarakat pada media sosial. Iklan layanan masyarakat pada penelitian ini diperoleh dari 10 akun, terdiri atas 1 akun organisasi anak dan 9 akun kementerian Indonesia yang dibatasi pada Januari 2020. Jenis penelitian ini adalah kualitatif dengan pendekatan deskriptif. Data pada penelitian ini berupa kata, frasa, klausa, serta kalimat yang mengandung makna impilkatur dalam iklan layanan masyarakat pada media sosial. Sumber data penelitian ini adalah iklan layanan masyarakat pada media sosial. Teknik pengumpulan data yang digunakan adalah teknik dokumentasi. Hasil penelitian yang diperoleh adalah makna implikatur sebanyak 3 makna, yakni imbauan (ajakan), larangan (sindiran) dan peringatan.
\end{abstract}

Kata Kunci: Analisis Wacana, Iklan Layanan Masyarakat, Implikatur

\section{PENDAHULUAN}

Penelitian ini mengkaji makna implikatur pada Iklan Layanan Masyarakat (ILM) di media sosial. Penelitian ini menarik dilakukan karena beberapa alasan berikut. Pertama, ILM memiliki makna atau pesan yang hendak disampaikan kepada sasaran iklan. Masyarakat umumnya hanya menaruh perhatian pada makna eksplisit dan tidak menghiraukan makna implisit (tersirat) dari ILM yang dibaca. Akibatnya, sering terjadi salah tafsir terhadap ILM yang dilakukan oleh masyarakat. Contohnya ILM yang dikeluarkan oleh pemerintah guna menggalakkan program $\mathrm{KB}$, yaitu "Dua Anak Cukup". Tujuan dikeluarkannya ILM tersebut adalah agar setiap orang tua dapat memantau perkembangan anak dengan baik. Orang tua dapat memberi perhatian dengan maksimal serta dapat memastikan setiap anak menerima hak yang cukup dan sesuai. Namun, iklan tersebut dimaknai oleh masyarakat bahwa pemerintah melarang masyarakat memiliki anak lebih dari dua. Hal ini karena adanya kata 'cukup' yang berarti 'tidak boleh ditambah lagi'.

Kedua, untuk dapat memahami makna implisit dari ILM, dibutuhkan pengkajian yang lebih dalam. Pengkajian tersebut dapat dilakukan menggunakan teori implikatur. Grice (dalam Ariani dkk, 2016:2) membagi implikatur menjadi dua jenis, yaitu implikatur konvensional (conventional implicature) dan implikatur percakapan (conversation implicature). Implikatur konvensional adalah implikasi pragmatik yang diperoleh langsung dari 
proses pemaknaan kata dan kalimat, bukan dari prinsip-prinsip percakapan. Implikatur ini tidak terikat pada konteks khusus, seperti gerak-gerik dan intonasi suara. Berbeda dengan implikatur konvensional, implikatur percakapan sangat tergantung pada konteks terjadinya percakapan agar dapat memahami maksud tuturan.

Iklan layanan masyarakat (ILM) dapat dijumpai di berbagai media, seperti media sosial. Banyak manfaat yang dapat dirasakan dengan hadirnya media sosial. Salah satunya dapat menunjang akses komunikasi pemasaran dan pengembangan iklan dari sejumlah perusahaan. Media sosial juga menjadi wadah yang menampung aspirasi dan gagasan masyarakat dari berbagai kalangan. ILM yang dimuat di media sosial mengalami pembaharuan hampir setiap hari dengan isi pesan yang beragam. Berdasarkan alasan di atas, peneliti tertarik untuk melakukan penelitian terhadap ILM dengan memfokuskan pada makna implikatur dari ILM yang tersebar pada media sosial, khususnya pada 1 akun organisasi anak (Unicef) dan 9 akun Kementerian Republik Indonesia.

\section{LANDASAN TEORI}

Secara etimologi, Douglas (dalam Rahmayanti, 2016:11) mengatakan bahwa wacana berasal dari bahasa Sanskerta, yaitu wac/wak/vak yang artinya 'berkata', 'berucap'. Kata tersebut kemudian mengalami perubahan menjadi 'wacana'. Bentuk 'ana' yang muncul di belakang merupakan suatu akhiran yang berfungsi sebagai pembeda atau nominalisasi. Singkatnya, kata wacana dapat diartikan sebagai 'perkataan' atau 'tuturan'. Kridalaksana (dalam Rahmayanti, 2016:11) mengatakan bahwa wacana atau discourse adalah satuan bahasa terlengkap yang merupakan satuan gramatikal terbesar. Wacana direalisasikan dalam bentuk karangan utuh (novel, buku, seri ensiklopedia, dan sebagainya), seperti paragraf, kalimat, atau bahkan kata yang membawa amanat yang lengkap.

Tarigan (dalam Rahmayanti, 2016:11) melanjutkan bahwa istilah wacana digunakan tak hanya mencakup percakapan atau obrolan, tetapi juga mencakup tulisan, seperti laporan ilmiah, dan sandiwara iklan. Maka, dapat disimpulkan bahwa wacana adalah proses komunikasi, baik satuan lisan maupun tulisan yang memiliki keterkaitan (kohesi) dan keterpaduan (koheren) serta memiliki makna yang utuh. Wacana memiliki cakupan luas, tidak hanya percakapan atau obrolan, tetapi juga dapat berupa tulisan, sandiwara iklan, laporan ilmiah, dan lain sebagainya.

Pujiyanto (dalam Rahmayanti, 2016:1) mengatakan bahwa ILM adalah iklan yang digunakan untuk menyampaikan informasi, mengajak, serta mendidik masyarakat dengan tujuan akhir bukan untuk mendapatkan keuntungan ekonomi, melainkan keuntungan sosial. Keuntungan sosial yang dimaksud ialah adanya penambahan informasi atau pengetahuan, kesadaran sikap, serta perubahan perilaku yang berkaitan dengan topik pembahasan pada iklan yang dimuat. Sejalan dengan itu, Kasali (dalam Santoso, 2015:5) menggambarkan ILM sebagai kampanye sosial berupa sebuah anjuran, imbauan, larangan hingga berupa ancaman yang ditujukan kepada masyarakat melalui media. Imbauan yang disertakan dalam ILM disampaikan menggunakan kalimat yang bersifat persuasif. Berdasarkan sifat-sifat tersebut dan topik yang diangkat pada ILM, dapat disimpulkan bahwa iklan ini berusaha untuk mengimbau masyarakat agar lebih peduli pada keadaan sosial masyarakat di sekitarnya.

Konsep implikatur pertama kali diungkapkan oleh Paul Grice (dalam Ariani, 2016:2) pada artikelnya yang berjudul Logic and Conversation bahwa implikatur adalah ujaran yang menyiratkan sesuatu yang berbeda dengan 
yang sebenarnya diucapkan. Mey (dalam Nadar, 2009:60) mengungkapkan implikatur 'implicature' berasal dari kata kerja to imply dan bentuk dari kata bendanya adalah implication. Kata kerja tersebut berasal dari bahasa latin, yaitu plicare yang berarti to fold atau 'melipat'. Maka, dapat diartikan untuk mengerti isi dari sesuatu yang dilipat atau disimpan adalah dengan cara membukanya. Dengan kata lain, untuk memahami maksud seorang penutur, mitra tutur harus selalu melakukan interpretasi pada tuturantuturannya.

Leech (dalam Nadar, 2009:60) menyebutkan bahwa menginterpretasikan tuturan sebenarnya merupakan usaha untuk menduga atau membuat hipotesis. Bach dan Harnish (dalam Ariani dkk., 2016:2) mengatakan bahwa pada hakikatnya implikatur adalah makna yang terselubung dari sebuah tuturan. Implikatur adalah ujaran atau ungkapan yang menyiratkan sesuatu yang berbeda dari yang sebenarnya diucapkan. Maka, konsep implikatur digunakan untuk menjelaskan perbedaan yang sering terjadi antara 'apa yang diujarkan' dan 'apa yang diimplikasi' atau 'apa yang dimaksud'. Sejalan dengan pendapat tersebut, Levinson (dalam Nadar, 2009:61) mengatakan bahwa implikatur memberikan penjelasan eksplisit dari sebuah tuturan agar dapat mengimplikasikan atau memaknai lebih luas dari apa yang dituturkan.

Implikatur berperan penting dalam sebuah tuturan, baik lisan maupun tulisan. Implikatur akan memberikan penjelasan tentang makna tersirat atau maksud yang disampaikan secara tidak langsung dari sebuah tuturan agar menjadi jelas dan mudah dipahami. Dengan demikian, implikatur digunakan untuk menjelaskan lebih lanjut maksud dari sebuah tuturan yang disampaikan. Implikatur juga digunakan untuk memahami makna tersembunyi atau tersirat yang terdapat dalam sebuah tuturan. Makna tersirat tersebut dapat berupa saran, perintah, keinginan dan semacamnya yang tidak disampaikan secara lugas.

\section{METODE PENELITIAN}

Penelitian ini menggunakan pendekatan kualitatif. Pendekatan kualitatif adalah pendekatan penelitian yang digunakan untuk meneliti pada kondisi objek yang alamiah dan peneliti sebagai instrumen kunci, analisis data bersifat induktif, dan hasil penelitian ini lebih ditekankan pada makna dari pada generalisasi (Sugiyono, 2018:9). Pendekatan ini dipilih karena sesuai dengan orientasi masalah dan sumber data yang diteliti. Jenis penelitian ini adalah deskriptif. Jenis penelitian ini dipilih karena sejalan dengan tujuan penelitian untuk mendeskripsikan makna implikatur dari wacana ILM pada media sosial khususnya akun kementerian dan organisasi anak pada Instagram.

Data penelitian ini adalah kata, frasa, klausa, serta kalimat yang mengandung makna impilkatur pada ILM yang dipublikasikan di Instagram. ILM yang diteliti berupa foto dengan tulisan di dalamnya. Maka, sumber data penelitian ini adalah foto ILM pada aplikasi Instagram. Akun kementerian dan organisasi anak dipilih karena merupakan badan atau organisasi terpercaya yang diakui dan diterima oleh masyarakat. Data yang diambil dibatasi pada Januari 2020. Januari dipilih karena bertepatan dengan tahun baru. Umumnya, awal tahun dimanfaatkan untuk menyampaikan imbauan kepada masyarakat ke arah yang lebih baik dari tahun sebelumnya. Selain itu, pada Januari 2020 juga terjadi beberapa peristiwa yang menyita perhatian publik, seperti banjir dan kebakaran. Pada momentum seperti ini akan ada banyak ILM yang dipublikasikan dengan tujuan memberi solusi dari permasalahan yang terjadi. Kalangan kementerian dan pihak organisasi anak 
juga akan memberi perhatian lebih demi kepentingan khalayak ramai.

Terdapat 10 akun yang menjadi sumber data penelitian ini. Akun ini dipilih karena lebih banyak memberikan informasi dibandingkan akun-akun lainnya berupa ILM dalam bentuk foto. Selain itu, peneliti juga memperhatikan akun dengan jumlah pembaharuan informasi terbanyak dalam satu hari. Dengan begitu, proses pengumpulan data akan menjadi lebih mudah serta akan memperoleh data yang cukup. Sepuluh akun yang menjadi sumber data adalah: (1) Unicef Indonesia (@unicefindonesia),

Kementerian

BUMN (@kementerianbumn), (3) Kementerian Kesehatan RI (@kemenkes_ri), (4) Kementerian Agama RI (@kemenag_ri), (5) Kementerian Perempuan dan Anak (@kemenppa), (6) Kemenristek BRIN (Kementerian Riset dan Teknologi) (@kementerianristekbrin),

Kementerian Perhubungan RI (@kemenhub151), (8) Kementerian Sekretariat Negara (@kemensetneg.ri), (9) Kementerian Sosial RI (@kemensosri), (10) Kementerian Ketenagakerjaan (@kemnaker).

Pada penelitian ini, data yang diperoleh bersumber dari dokumen berupa foto atau gambar dengan tulisan di dalamnya. Sugiyono (2017:240) mengatakan bahwa dokumen dapat berupa tulisan, gambar, atau karya-karya monumental dari seseorang. Untuk itu, sesuai dengan data yang akan dikaji, peneliti hanya akan menggunakan satu teknik pengumpulan data, yaitu teknik dokumentasi.

Teknik dokumentasi adalah proses pengumpulan data dengan cara mengutip dokumen dari beberapa sumber, lalu dianalisis. Teknik dokumentasi pada penelitian ini adalah: (1) Pertama, peneliti mencari data pada sumber data, (2) Selanjutnya, data tersebut dikumpulkan sampai seluruhnya terkumpul dalam waktu 1 bulan yang dibatasi pada Januari
2020, (3) Setelah semua data terkumpul, peneliti menganalisis data yang telah diperoleh.

Teknik analisis data penelitian ini adalah: (1) Mengumpulkan data dari sumber yang telah disebutkan dengan jangka waktu selama satu bulan, (2) Setelah semua data terkumpul, peneliti mengelompokkan ILM berdasarkan sumber akun dan melakukan analisis secara konseptual dan kontekstual guna menemukan makna implikatur yang terdapat pada data sesuai dengan rumusan masalah, (3) Hasil analisis kemudian disimpulkan untuk dideskripsikan sebagai hasil dari penelitian.

\section{HASIL DAN PEMBAHASAN}

Setelah dilakukan analisis pada ILM di media sosial edisi Januari 2020, ditemukan sebanyak tiga jenis makna implikatur. Berikut ini adalah pembahasan mengenai hasil penelitian makna implikatur yang terdapat pada media sosial.

1) Salah Satu Jenis Makna Impikatur Berupa Makna Imbauan

Imbauan adalah pernyataan yang mengandung makna anjuran, ajakan, atau permintaan agar melakukan sesuatu berdasarkan tujuan. ILM pada media sosial edisi 2020 terdapat kalimat tanya yang bila dianalisis justru bermakna imbauan atau ajakan untuk memahami sesuatu. Hal ini ditemukan pada ILM dari akun Unicef edisi 19 Januari 2020 (data 15). Hal ini selaras dengan konsep implikatur yang diungkapkan oleh Levinson (dalam Ariani dkk., 2016). Levinson mengungkapkan bahwa konsep implikatur dapat digunakan untuk memberikan penjelasan suatu tuturan yang berbentuk pertanyaan dapat bermakna perintah atau imbauan. 


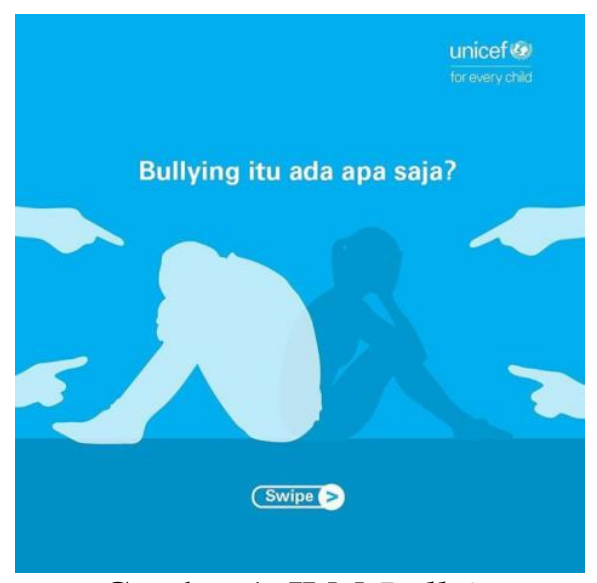

Gambar 1. ILM Bullying

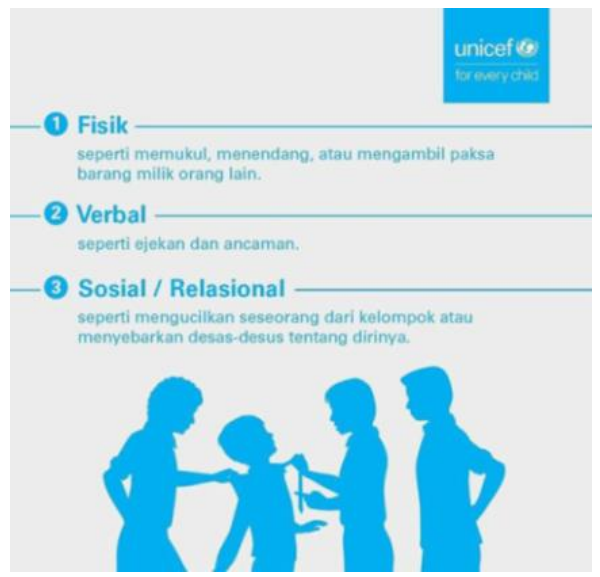

Gambar 2. ILM Bullying

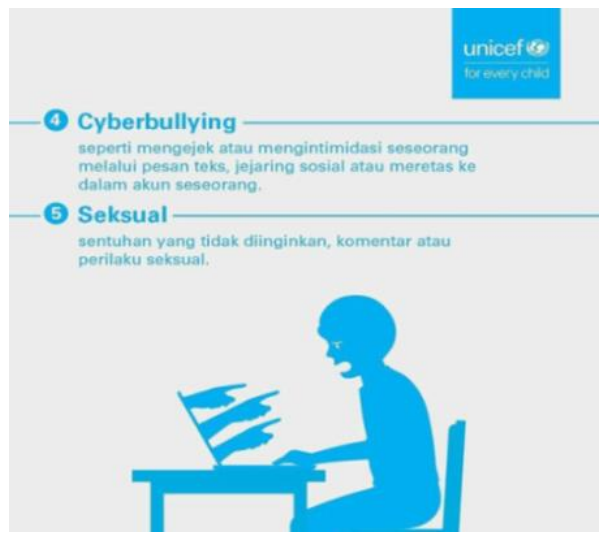

Gambar 4. ILM Bullying

a) Konseptual

Secara konseptual, ILM ini memaparkan bentuk-bentuk dari bullying disertai contoh. Hal ini agar bentuk dari bullying dapat dengan mudah dipahami oleh pembaca. ILM tersebut memaparkan 5 bentuk bullying, yaitu fisik, verbal, sosial/relasional, cyberbullying, dan seksual. Kalimat bullying itu ada apa saja? pada gambar 4.16 sebagai pengantar dari ILM ini.

b) Kontekstual

Secara konseptual, ILM ini berisi informasi dan pengetahuan baru mengenai bentuk-bentuk bullying agar masyarakat mengenal dengan baik segala bentuknya. Bullying adalah salah satu perilaku buruk kepada orang lain tanpa alasan yang jelas. Tindakan mengejek umumnya sering terjadi di masyarakat dan tidak lagi dianggap serius. ILM ini menjadi pengingat agar pembaca atau masyarakat selalu menjaga setiap perbuatan dan perilaku. Kalimat bullying itu ada apa saja? bermakna gambaran tentang kurangnya pengetahuan masyarakat tentang bentuk dari bullying itu sendiri.

c) Implikatur

Dengan demikian, implikatur pada ILM ini adalah imbauan untuk mengenal dengan baik bentuk-bentuk dari bullying dapat dilakukan pencegahan. ILM ini juga bermakna imbauan agar menjaga perbuatan kita dan bersikap baik kepada orang lain. Dengan begitu, tidak membuka kemungkinan seseorang menjadi pelaku bullying.

2) Salah Satu Jenis Makna Impikatur Berupa Makna Sindiran atau Larangan

Sindiran adalah pernyataan yang mengandung makna cemooh, atau mencela orang lain atau sebuah tindakan yang disampaikan tidak secara langsung serta bertujuan agar hal tersebut tidak terulang kembali. Untuk itu, makna sindiran atau larangan disatukan. Makna implikatur berupa sindiran juga ditemukan dalam ILM pada media sosial edisi 2020. ILM tersebut berisi sindiran kepada masyarakat yang beralih dari rokok biasa ke rokok elektronik atau vape. ILM tersebut menyindir dan melarang masyarakat melakukan hal tersebut melalui klausa vape bukan solusi, disertai penjelasan bahaya menggunakan vape. Hal ini ditemukan pada akun Kementerian 
Kesehatan edisi 16 Januari 2020 (data 07). Hal ini sejalan dengan penjelasan Grice (dalam Ariani dkk., 2016:2) bahwa ketika suatu ujaran disampaikan dengan maksud menyindir atau mengkritik secara implisit, maka diharapkan tidak muncul kesalahpahaman dan ketersinggungan.



Gambar 4.35. ILM Bahaya Vape

a) Konseptual

Secara konseptual, ILM ini berisi informasi bahwa vape tidak dapat dijadikan pilihan ketika seseorang berhenti mengonsumsi rokok biasa. ILM ini ditujukan khusus kepada mantan perokok yang beralih menggunakan vape. Frasa bukan solusi bermakna bahwa vape bukan pilihan ketika seseorang ingin berhenti dari kecanduan rokok. ILM ini juga turut menjelaskan kandungan berbahaya dalam vape.

b) Konseptual

Secara konseptual, ILM ini menegur para perokok yang kini beralih menggunakan vape. Frasa bukan solusi bermakna bahwa mengganti rokok dengan vape telah menjadi tren dan dianggap sebagai solusi. Frasa tidak terbukti membantu bermakna bahwa vape dan rokok biasa tidak dapat membuat seseorang menghilangkan kebiasaan buruk menghirup asap. Klausa memiliki kandungan yang sama bermakna bahwa keduanya sama-sama berbahaya bagi kesehatan penikmatnya.

c) Implikatur
Dengan demikian, makna implikatur yang terdapat pada ILM ini adalah makna sindiran atau larangan. Sindiran tersebut secara khusus ditujukan bagi pengguna rokok biasa yang beralih menggunakan vape atau rokok elektronik. Hal ini karena vape memiliki bahaya yang sama. Maka, pengguna vape maupun rokok biasa tidak ada bedanya.

3) Salah Satu Jenis Makna Impikatur Berupa Makna Peringatan

Peringatan adalah pernyataan yang mengandung makna teguran atau kritik terhadap sesuatu. Makna implikatur berupa peringatan juga ditemukan dalam ILM pada media sosial edisi Januari 2020. Salah satu diantaranya ditemukan pada akun Kementerian Ketenagakerjaan edisi 20 Januari 2020 (data 08). ILM ini menjelaskan kewajiban pengusaha terhadap pekerja perempuan yang telah diatur dalam undang-undang Kepmenakertrans No.224 Tahun 2003. Kewajiban adalah tugas atau keharusan. Kewajiban tersebut telah diatur dalam undang-undang, maka bila tidak dilaksanakan akan ada konsekuensi atau akibat yang akan ditanggung. Dengan demikian, ILM ini memperingati para pengusaha untuk melaksanakan kewajibannya sesuai dengan hukum tertulis atau akan menerima sanksi.



Gambar 4.79. ILM Kewajiban Pengusaha 


\section{a) Konseptual}

Secara konseptual, ILM ini berisi informasi kewajiban setiap pengusaha yang memiliki pekerja perempuan pada jam malam. Frasa kewajban pengusaha bermakna hal-hal yang harus dipenuhi atau dilakukan oleh seorang pengusaha. Kepmenakertrans No.224 Tahun 2013 bemakna bahwa telah ada peraturan tertulis, serta akan ada sanksi bila peratutan ini tidak dilaksanakan. ILM ini memaparkan 3 poin kewajiban sesuai dengan peraturan tertulis.

b) Kontekstual

Secara kontekstual, ILM ini berisi penjelasan kewajiban pengusaha terhadap karyawan perempuan yang tetap bekerja pada malam hari. Pukul 23.0007.00 adalah jam malam yang dimaksud. ILM ini bermakna sindiran bagi pengusaha yang masih tidak melakukan kewajiban sebagaimana yang telah ditetapkan. Poin 1, bermakna menjaga kesehatan pekerja. Poin 2, memberikan dan memastikan keamaan pekerja karena pada pukul 23.00-07.00 adalah waktu rentan terjadinya kejahatan. Poin 3, menjaga keamanan pekerja dalam perjalanan pulang.

c) Implikatur

Dengan demikian, makna implikatur pada ILM ini adalah makna peringatan. Para pengusaha yang mempekerjakan pekerja perempuan pada jam malam agar melaksanakan kewajiban sesuai peraturan yang berlaku. ILM juga sebagai pengingat agar pekerja tetap aman dan pengusaha tidak terkena sanksi.

\section{4) Salah Satu ILM yang Tidak Memiliki Makna Implikatur}

ILM yang tidak memiliki makna implikatur sebagian besar adalah ILM yang memuat peringatan hari-hari besar. Jadi, dapat disimpulkan bahwa tidak semua ILM memiliki makna implikatur.



Gambar 4.54. ILM Hari Gizi Nasional

a) Konseptual

Secara konseptual, ILM ini berisi peringatan Hari Gizi Nasional. Hal ini dapat terlihat jelas pada frasa Hari Gizi Nasional. frasa tersebut menjadi satusatunya tulisan yang tertera pada ILM tersebut. Hari Gizi Nasional diperingati setiap tanggal 25 Januari.

b) Kontekstual

Secara kontekstual, ILM ini bertujuan untuk memperingati hari gizi nasional ke-60. Hari gizi nasional diperingati setiap tanggal 25 Januari. Frasa Hari Gizi Nasional menjadi satusatunya tulisan pada ILM tersebut, maka dapat dikatakan tidak ada makna lain yang ingin disampaikan pada ILM ini.

c) Implikatur

Dengan demikian, ILM ini tidak memiliki makna implikatur. Hal ini karena tidak ada makna lain yang ingin disampaikan selain ucapan selamat memperingati Hari Gizi Nasional. Maka dapat dikatakan bahwa makna yang ingin disampaikan pada ILM tersebut dapat tersampaikan dengan jelas.

Setelah dilakukan penelitian, ILM pada media sosial edisi Januari 2020 terdapat 3 macam makna implikatur, yaitu berupa imbauan (ajakan), larangan (sindiran), dan makna implikatur berupa peringatan. Dari 68 data, 14 di antaranya tidak memiliki makna implikatur. ILM yang tidak memiliki makna implikatur sebagian besar adalah ILM yang memuat peringatan hari-hari besar. Jadi, dapat disimpulkan bahwa tidak semua ILM memiliki makna implikatur. Melalui analisis makna implikatur, ditemukan 
bahwa ada makna lain yang lebih luas dari apa yang disampaikan pada setiap ILM dengan tujuan yang berbeda. Implikatur akan memberikan penjelasan tentang makna tersirat atau makna yang disampaikan secara tidak langsung dari sebuah tuturan, baik secara lisan maupun tulisan agar menjadi jelas dan mudah dipahami.

\section{PENUTUP}

Berdasarkan analisis yang telah dilakukan dapat disimpulkan bahwa makna implikatur yang ditemukan dalam wacana ILM pada media sosial yang dibatasi pada edisi Januari 2020, ialah berupa implikatur larangan atau sindiran, implikatur imbauan, dan implikatur peringatan. Dari hasil yang diperoleh, makna implikatur yang paling banyak ditemui adalah makna implikatur imbauan. Makna imbauan paling banyak ditemukan karena pada ILM di media sosial lebih didominasi oleh anjuran untuk melakukan sesuatu yang bertujuan membawa perubahan yang lebih baik di masyarakat dengan penyampaian yang tidak langsung.

Urutan selanjutnya berupa implikatur peringatan. Implikatur peringatan sebagai tindakan teguran kepada beberapa golongan masyarakat secara tidak langsung agar tidak menyudutkan serta tidak memunculkan kesalahpahaman dan ketersinggungan. Paling sedikit makna implikatur yang ditemukan adalah berupa makna sindiran atau larangan. Makna implikatur banyak ditemukan pada penelitian ini. Hal ini karena akun organisasi besar seperti Unicef dan akun Kementerian Republik Indonesia berusaha mengatasi masalah yang ada di tengah-tengah masyarakat dengan cara yang sopan dan tidak menyinggung atau menyudutkan pihak manapun.
DAFTAR PUSTAKA

Ariani, Ida Ayu Putu Nikke Widhi dkk. 2016. "Implikatur Pada Iklan Layanan Masyarakat". Jurnal JPBSI Undiksha, (Online). Vol.4, No.2,

(https://ejournal.undiksha.ac.id).

diakses pada 21 Desember 2019.

Nadar, F.X. 2009. Pragmatik dan Peneitian Pragmatik. Yogyakarta: Graha Ilmu.

Rahmayanti, Utari. 2016. "Analisis Wacana Iklan Layanan Masyarakat pada Harian Kompas Edisi Agustus 2015". Skripsi (Internet), (http://repository.ump.ac.id). diakses tanggal 4 Desember 2019.

Santoso, Hari. 2015. "Upaya Meningkatkan Minat dan Budaya Membaca Buku Melalui Iklan Layanan Masyarakat". Artikel (Online). Jilid-, No.-, (http://library.um.ac.id). diakses tanggal 13 Desember 2019.

Sugiyono. 2017. Metode Penelitian Kualitatif, Kuantitatif, $R$ dan $D$. Bandung: Alfabeta.

Sugiyono. 2018. Metode Penelitian Kualitatif. Bandung: Alfabeta. 